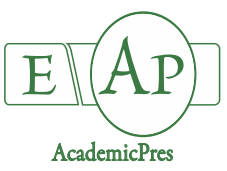

Cheng S et al. (2020)

Notulae Botanicae Horti Agrobotanici Cluj-Napoca 48(2):558-571

DOI: $10.15835 /$ nbha 48211916

Research Article

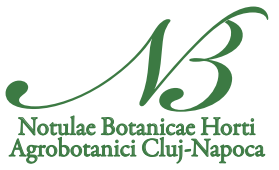

\title{
Molecular responses of arbuscular mycorrhizal fungi in tolerating root rot of trifoliate orange
}

\author{
Shen $\mathrm{CHENG}^{1}$, Li TIAN ${ }^{1}$, Ying-Ning ZOU ${ }^{1 *}$, Qiang-Sheng WU1,2*, \\ Kamil KUČA ${ }^{2}$, Popy BORA ${ }^{3}$ \\ ${ }^{1}$ Yangtze University, College of Horticulture and Gardening, Jingzhou, Hubei 434025, \\ China; 512760562@qq.com;1943241801@qq.com; zouyingning@163.com (*correspondingauthor); \\ wuqiangsh@163.com (*corresponding author) \\ ${ }^{2}$ University of Hradec Kralove, Faculty of Science, Department of Chemistry, Hradec Kralove 50003, Czech Republic; kamil.kuca@ubk.cz \\ ${ }^{3}$ Assam Agricultural University, Department of Plant Pathology, Jorhat, India; pbora.sonitpur10@gmail.com
}

\begin{abstract}
Arbuscular mycorrhizal fungi (AMF) enhance plant disease resistance, while the underlying mechanisms in the molecular levels are not yet known. In this study, five-leaf-old trifoliate orange seedlings were inoculated with Funneliformis mosseae for 14 weeks and subsequently were infected by a citrus root rot pathogen Phytophthora parasitica by 7 days. The transcriptome results by Illumina HiSeq 4000 revealed that the percentage of Q30 bases reached $92.99 \%$ or above, and 29696 unigenes were annotated in atotal of 63531 unigenes. 654 and 103 differentially expressed genes (DEGs) were respectively annotated in AMF-inoculated versus non-AMF-inoculated plants under non-infection and infection with $P$. parasitica, respectively, whilst these DEGs were related to defense mechanisms, signal transduction mechanisms and secondary metabolites biosynthesis. Forty-two genes were functionally annotated as the putative 'defense mechanism', whilst AMF inoculation induced 1 gene down-regulated and 3 genes up-regulated under $P$. parasitica infection. AMF inoculation stimulated more genes linked to signal transduction mechanism down-regulated than non-AMF plants. Eight genes were involved in secondary metabolites biosynthesis in AMF versus non-AMF seedlings under $P$. parasitica-infection conditions. Such transcriptome database provided total information in the molecular levels regarding mycorrhizal roles in tolerating Phytophthora parasitica infection.
\end{abstract}

Keywords: arbuscular mycorrhizal fungi; citrus; pathogen; RNA-Seq

\section{Introduction}

Citrus trees are susceptible to a large number of diseases, including root rot. The main pathogen of citrus root rot in China is Phytophthora parasitica (Tian et al., 2018). Soil arbuscular mycorrhizal fungi (AMF) can build mutual symbionts with most plants (including citrus), viz. arbuscular mycorrhizas (AMs) (He et al., 2019, 2020; Wu et al., 2019; Zhang et al., 2020). Many studies showed a crucial function of AMF on increased plant disease resistance (Xie et al., 2019; Zhang et al., 2019; Gao et al., 2020). Ozgonen et al. (2010) inoculated AMF 
on Arachis hypogaea plants to study its effects on stem rot caused by Sclerotium rolfsii, and found that all the selected AMF species, including Funneliformis etunicatum, F. clarum, F. caledonium, and F. fasciculatum collectively reduced the incidence of stem rot. Inoculation with F. mosseae and Rhizophagus irregularis also mitigated symptoms of root rot in Aphanomyces euteiches-infected pea (Bodker et al., 1998; Slezack et al., 1999). As a result, it seems that AMF has the capacity to mitigate root rot, whereas the underlying mechanisms are not yet known.

Transcriptome analysis with high-throughput sequencing (RNA-Seq), a new molecular biology technique, is designed to elucidate the molecular responses to bacteria-disease occurrence and fungi-disease occurrence (Gao et al., 2016). RNA-Seq technology also identifies responsive genes of pathogen infection from large-scale transcripts of plants, and further analyzes disease resistance mechanisms or pathogenic mechanisms through gene function analysis. Yap et al. (2005) found wound-induced proteins to activate the phosphorylation cascade in mycorrhiza-inoculated-Medicago truncatula by RNA-Seq. Dao et al. (2011) found a chalcone synthase from the transcriptome data of $M$. truncatula inoculated with Glomus versiforme, which could enhance plant disease resistance. Lambais and Mehdy (2010) found that in transcriptome of Phaseolus vulgaris plants, inoculation with Rhizophagus irregularis up-regulated chitinase and $\beta$-1,3-glucanase expression in differentially expressed genes (DEGs) to collectively hydrolyze cell walls of pathogenic fungi (EsquerréTugayé et al., 2000; Hu et al., 2017). These results conclude that RNA-Seq could reveal the potential mechanisms at the molecular level in disease resistance. However, information regarding AMF-enhanced resistance of root rot in molecular levels is scarce.

The objective of the present study was to establish the transcriptome of trifoliate orange (Poncirus trifoliata L. Raf.) roots after inoculated with an arbuscular mycorrhizal fungus Funneliformis mosseae and a citrus root rot pathogen Phytophthora parasitica, and to identify DEGs and their metabolic pathways after AMF inoculations.

\section{Materials and Methods}

\section{Experimental design}

The experiment consisted of a completely randomized block design with the inoculation with or without Funneliformis mosseae and the infection with or without Phytophthora parasitica. The four treatments were (i) the inoculation without $F$. mosseae and P.parasitica (-F.m-P. p), (ii) the inoculation with $F$. mosseae and without $P$.parasitica $(+F \cdot m-P$. $p$ ), (iii) the inoculation with $P$.parasitica and without $F$. mosseae $(-F . m+P$. $p$ ), and (iv) the inoculation with $F$. mosseae and $P$. parasitica $(+F . m+P . p)$. Each of four treatments was replicated five times.

\section{Plant culture and pathogen inoculation}

The arbuscular mycorrhizal fungal strain, Funneliformis mosseae (Nicol. \& Gerd.) Schüßler \& Walker [BGC XZ02A], was used in this study and also propagated with white clover in pots for 3 months, and mycorrhizal inoculums contained substrates, spores $(20$ spores/g), mycorrhizal hyphae, and infected root pieces.

Three 5-leaf-old trifoliate orange seedlings grown in autoclaved $\left(0.11 \mathrm{MPa}, 121^{\circ} \mathrm{C}, 2 \mathrm{~h}\right)$ sands were planted into 1.6-L plastic pots supplied with $1.5 \mathrm{~kg}$ of autoclaved substrates of soil and sand $(5: 1, \mathrm{v} / \mathrm{v})$. At the same time, mycorrhizal inoculums ( $90 \mathrm{~g}$ per pot) of $F$. mosseae were applied into the rhizosphere of seedlings as the AMF treatment. In addition, an equal number of autoclaved mycorrhizal inoculums plus $2 \mathrm{~mL}$ filtrate $(25$ $\mu \mathrm{m}$ filter) of the inoculum were mixed with growth substrates as the non-AMF treatment. All the seedlings 
were grown in a greenhouse for 14 weeks with 721 to $967 \mu \mathrm{mol} / \mathrm{m}^{2} / \mathrm{s}$ photon flux, $25 / 19^{\circ} \mathrm{C}$ average day $/$ night temperature, and $75-85 \%$ relative humidity.

The pathogenic fungus $P$. parasitica was freely provided by the Citrus Research Institute, Chinese Academy of Agricultural Sciences. Such pathogenic infection was conducted out according to Li $e t$ al. (2014) with slight modification. Before the infection, the $P$. parasitica was cultured on potato dextrose agar (PDA) at $28^{\circ} \mathrm{C}$ for one week. The $70 \%$ alcohol solution was utilized to sterilize the root neck of trifoliate orange seedlings for $10 \mathrm{~s}$. After rinsed with sterilized water, a sterilized needle was used to make a wound, and 5-mm-diameter mycelial plug of $P$. parasitica was placed onto the wound. The non- $P$.parasitica infection treatment received sterilized PDA with same diameter. Subsequently, moistly sterilized absorbent cotton covered on the wound. After 7 days of the pathogen infection, the treated seedlings were harvested.

\section{Illumina sequencing and data processing}

The extraction of total RNA in the roots was done using an EASY spin Plus plant RNA kit (Aidlab Biotecnolohies CO. Ltd, China). DNAase (Takara Bio. Inc, Japan) was utilized to remove genomic DNA. After checked RNA yield, purity, and integrity, a total of the 12 RNA samples (three replicates (seedlings)/treatment) with $10 \mu \mathrm{g}$ total RNA per replicate were sent for RNA-Seq by means of Illimina Genome Analyzer at Biomaker (Beijing, China) in 2017. After purified and concentrated polyadenylated mRNAs with dT-conjugated magnetic beads, directional RNA-Seq library was prepared. After reversed transcription from RNA to cDNA, PCR products with 200-500 bp were purified and quantified for sequencing. Whereafter, Illumina HiSeq 4000 platform was used to sequence the cDNA libraries of each treated root. The raw data were gathered by the sequencer. The raw sequence reads were uploaded into NCBI, in which the SRA number is SRR9665367.

The reads containing two $\mathrm{N}$ were eliminated, the adaptor was changed according to adapter information, and then the low-quality reads were trimmed to obtain clean data. Trinity software was used to assemble the clean data and acquire unigenes libraries of each sample.

\section{Identification and annotation of DEGs}

To identify DEGs, the edgeR software was utilized. Statistical significance indexes were established based on the fold change $\left(\left|\log _{2} \mathrm{FC}\right| \geq 2\right)$ and $\mathrm{p}$-value $(\mathrm{p} \leq 0.01)$. BLAST software (version 2.2.26) was used to compare DEGs with databases of COG, eggNOG4.5, GO, KOG, KEGG, NR, and Swiss-Prot to obtain annotation information. BLAST parameters e-value not greater than $1 \times \mathrm{e}^{-5}$ and HMMER parameters e-value not greater than $1 \times \mathrm{e}^{-10}$ were selected.

\section{Results}

\section{Evaluation and splicing of sequencing data}

A total of $85.80 \mathrm{~Gb}$ of clean data was obtained. The clean data of each samples reached $6.32 \mathrm{~Gb}$, and the Q30 bases percentage was $93 \%$ or above (Table 1). As a result, the sequencing data in this study had good quality, which could meet the need for subsequent analysis. A total of 63531 unigenes were obtained by splicing, with a total length of $53714816 \mathrm{nt}$ and N50 length of $1715 \mathrm{nt}$ (Table 2). Among them, 15449 unigenes were longer than $1000 \mathrm{bp}$, and the average length of unigenes was $845.49 \mathrm{bp}$. In short, a high-quality transcriptome assembly database was obtained. 
Table 1. Evaluation statistics of sample sequencing data

\begin{tabular}{|c|c|c|c|c|}
\hline Samples & Read number & Base number & GC content & $\% \geq$ Q30 \\
\hline$-F \cdot m-P \cdot p 1$ & 23134686 & 6914175344 & $44.13 \%$ & $93.27 \%$ \\
\hline$-F \cdot m-P \cdot p 2$ & 27933199 & 8338166762 & $43.77 \%$ & $93.52 \%$ \\
\hline$-F \cdot m-P \cdot p 3$ & 24333709 & 7266230434 & $43.98 \%$ & $93.29 \%$ \\
\hline$-F \cdot m+P \cdot p 1$ & 23036807 & 6885404058 & $43.83 \%$ & $93.24 \%$ \\
\hline$-F \cdot m+P \cdot p 2$ & 23153407 & 6927738352 & $43.66 \%$ & $93.46 \%$ \\
\hline$-F \cdot m+P . p 3$ & 24267311 & 7262604330 & $43.42 \%$ & $93.39 \%$ \\
\hline$+F \cdot m-P \cdot p 1$ & 23614036 & 7063838768 & $43.99 \%$ & $92.99 \%$ \\
\hline$+F \cdot m-P \cdot p 2$ & 23095707 & 6901774502 & $43.84 \%$ & $93.22 \%$ \\
\hline$+F \cdot m-P \cdot p 3$ & 22801487 & 6813786472 & $44.37 \%$ & $93.33 \%$ \\
\hline$+F \cdot m+P \cdot p 1$ & 21160512 & 6321620442 & $43.93 \%$ & $93.07 \%$ \\
\hline$+F \cdot m+P \cdot p 2$ & 22483147 & 6719494016 & $43.81 \%$ & $93.18 \%$ \\
\hline$+F \cdot m+P \cdot p 3$ & 28074161 & 8387992504 & $43.78 \%$ & $93.40 \%$ \\
\hline
\end{tabular}

Abbreviations: $+F . m$ : inoculation with Funneliformis mosseae; $-F . m$ : inoculation without Funneliformis mosseae; $+P$. $p$ : infection with Phytophthora parasitica; -P.p: infection without Phytophthora parasitica.

Table 2. Statistics of assembly results

\begin{tabular}{|c|c|c|c|c|}
\hline & Total number & Total length & Mean length & N50 length \\
\hline Transcript & 171478 & 287218347 & 1674.96 & 2617 \\
\hline Unigene & 63531 & 53714816 & 845.49 & 1715 \\
\hline
\end{tabular}

\section{Screening of DEGs}

Depending on the relative expression levels of the regulated samples, the DEGs were defined as upregulated and down-regulated genes. Compared with -F. $m-P . p$ treatment, $-F . m+P . p$ treatment induced 99 genes up-regulated and 111 genes down-regulated in roots, while $+F . m-P . p$ treatment induced 630 genes upregulated and 662 genes down-regulated in roots (Table 3). Compared with $-F . m+P$. $p$ treatment, $+F . m+P$. $p$ treatment induced 36 genes up-regulated and 151 genes down-regulated in roots, and $+F . m-P$. $p$ treatment modulated 665 genes up-regulated and 578 genes down-regulated.

Table 3. Differentially expressed gene numbers between different treated groups

\begin{tabular}{|c|c|c|c|}
\hline Differential treatment groups & DEGs numbers & Up-regulated DEGs & Down-regulated DEGs \\
\hline$-F \cdot m-P \cdot p$ vs $-F \cdot m+P \cdot p$ & 210 & 99 & 111 \\
\hline$-F \cdot m-P \cdot p$ vs $+F \cdot m-P \cdot p$ & 1292 & 630 & 662 \\
\hline$-F \cdot m+P \cdot p$ vs $+F \cdot m+P \cdot p$ & 187 & 36 & 151 \\
\hline$+F \cdot m-P \cdot p$ vs $+F \cdot m+P \cdot p$ & 1243 & 665 & 578 \\
\hline
\end{tabular}

The abbreviations are the same as in Table 1 .

\section{GO functional enrichment of DEGs}

GO terms were assigned to gain an overall understanding of the 110, 654, 103, and 623 DEGs identified in the $-F . m-P . p$ vs $-F . m+P . p,-F . m-P . p$ vs $+F . m-P . p,-F . m+P \cdot p$ vs $+F . m+P \cdot p$, and $+F . m-P . p$ vs $+F . m+P$. $p$ analysis, respectively. The broad categories for the three major GO functional domains (biological process, cellular component, and molecular function) were shown (Figure 1). Compared with -F.m-P. $p$ treatment, $-F$. $m+P$. $p$ treatment induced a total of 110 DEGs annotated to the secondary node of GO database (Figure 1a). In the biological process, "biological regulation", "cellular process", "localization", "metabolic process", "response to stimulus", and "single-organism process" captured 22 (25\%), 58 (53\%), 22 (25\%), 68 (62\%), 33 (30\%) and 57 (52\%) unigenes, respectively. In the cellular components, "cell", "cell part", "membrane", and "organelle" annotated captured 41 (37\%), 23 (21\%), and 25 (23\%) unigenes, respectively. In the molecular 
function, "catalytic activity", "binding", and "transporter activity" captured 75 (68\%), 51 (46\%), and 13 (12\%) unigenes, respectively.

Compared with -F. m-P. $p$ treatment, $+F . m-P$. $p$ treatment induced a total of 654 DEGs annotated to the secondary node of GO database (Figure 1b). In the biological process, "metabolic process", "single-organism process", "cellular process", "response to stimulus", and "biological regulation" captured 369 (56\%), 292 (45\%), 277 (42\%), 156 (24\%) and 126 (19\%) unigenes, respectively. In the cellular component, "cell" (205,31\%), "cell part" (205, 31\%), "membrane" (163, 25\%), and "organelle" (127, 19\%) captured most of the annotated unigenes. In the molecular function, "catalytic activity" (395, 60\%), "binding" (295, 45\%), and "transporter activity" $(67,10 \%)$ captured most of the annotated unigenes.

Compared with $-F . m+P . p$ treatment, $+F . m+P . p$ treatment induced a total of 103 DEGs annotated to the secondary node of GO database (Figure 1c). In the biological process, "biological regulation" $(21,20 \%)$, "cellular process" (53, 48\%), "localization" (19, 18\%), "metabolic process" (57, 55\%), "response to stimulus" (30, 29\%), and "single-organism process" (41, 40\%) captured most of the annotated unigenes; In the cellular component, "cell" (42,41\%), "cell part" (42, 41\%), "membrane" (30, 29\%), and "organelle" (25, 24\%) captured most of the annotated unigenes. In the molecular function, only "catalytic activity" (57, 55\%) and "binding" $(54,52 \%)$ captured most of the annotated unigenes.

Compared with $+F . m-P . p$ treatment, $+F . m+P . p$ treatment induced a total of 623 DEGs annotated to the secondary node of GO database (Figure 1d). In the biological process, "metabolic process" (337, 54\%), "single-organism process" (274, 44\%), "cellular process" (255, 41\%), "response to stimulus" (157, 25\%), "biological regulation" $(112,18 \%)$, and "localization" (99, 16\%) captured most of the annotated unigenes. In the cellular component, "cell" (186, 30\%), "cell part" (186, 30\%), "membrane" (139, 22\%), and "organelle" $(117,19 \%)$ captured most of the annotated unigenes. In the molecular function, only "catalytic activity" (371, $60 \%)$ and "binding" $(267,43 \%)$ captured most of the annotated unigenes.

\section{COG classification of DEGs}

Compared with $-F . m-P$. $p$ treatment, $-F . m+P$. p treatment induced a total of 80 DEGs annotated to 19 COG classifications (Figure 2a). Among the 19 COG classifications, "general function prediction" catched most of the DEGs $(18,23 \%)$, followed by "transcription" (11, 14\%). Besides, "replication, recombination and repair", "posttranslational modification, protein turnover, chaperones", and "carbohydrate transport and metabolism" all catched 10 DEGs. In addition, 9 DEGs were captured by "secondary metabolites biosynthesis, transport and catabolism", indicating that these genes may be involved in the secondary metabolites biosynthesis of citrus. Additionally, 5 DEGs and 7 DEGs were annotated respectively to "signal transduction mechanisms" and "defense mechanisms", suggesting that these genes may play a role in resisting pathogen infection.

The $+F \cdot m-P$. $p$ treatment induced a total of 403 DEGs annotated to 22 COG classifications, relative to -F. $m$-P. $p$ treatment (Figure 2b). Among the 22 COG classifications, "general function prediction" caught most of the DEGs $(125,31 \%)$, followed by "signal transduction mechanisms" (66, 16\%), "transcription" (63, $16 \%)$, and "replication, recombination and repair" (60,15\%). Whereas, "secondary metabolites biosynthesis, transport and catabolism" and "defense mechanisms" captured 48 and 19 DEGs respectively, implying that these genes may participate in plant resistance enhancement induced by AMF.

Compared with $-F . m+P . p$ treatment, $+F . m+P . p$ treatment induced a total of 53 DEGs annotated to 18 COG classifications (Figure 2c). Among the 18 COG classifications, "general function prediction" caught most of the DEGs (15,28\%), followed by "transcription" (7, 13\%) and "signal transduction mechanisms" (7, $13 \%)$. In addition, "secondary metabolites biosynthesis, transport and catabolism" and "defense mechanisms" captured 4 DEGs, showing that these genes took part in plant resistance enhancement induced by AMF. 

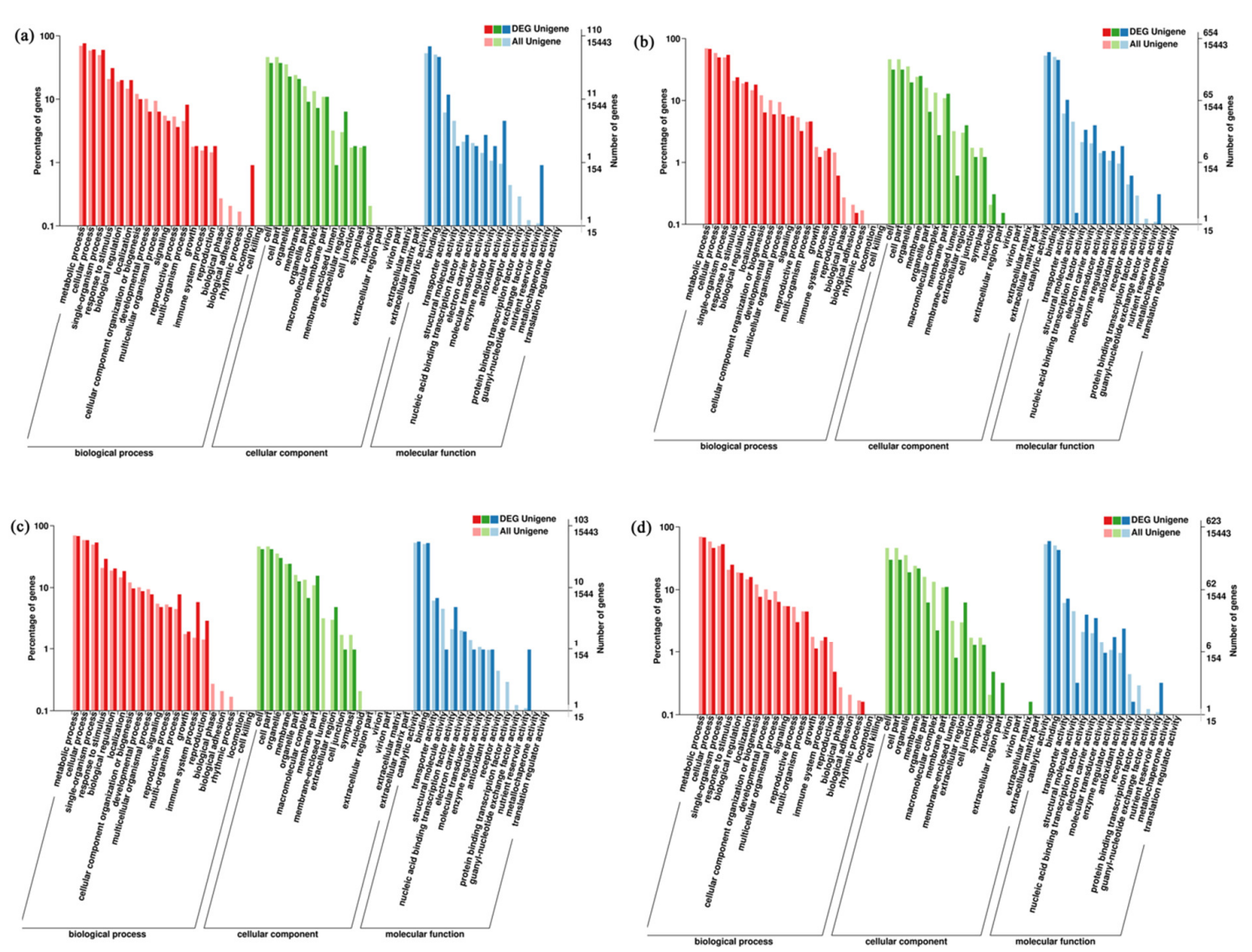

Figure 1. Gene ontology classifications of differentially expressed genes between $-F . m-P . p$ and $-F . m+P$. $p(\mathrm{a}),-F \cdot m-P \cdot p$ and $+F \cdot m-P \cdot p(\mathrm{~b}),-F \cdot m+P \cdot p$ and $+F \cdot m+P \cdot p(\mathrm{c})$, and $+F \cdot m-P \cdot p$ and $+F \cdot m+P \cdot p(\mathrm{~d})$, respectively. The abbreviations are the same as in Table 1

Compared with $+F \cdot m-P . p$ treatment, $+F \cdot m+P . p$ treatment induced a total of 346 DEGs annotated to 22 COG classifications (Figure 2d). Among the 22 COG classifications, "general function prediction" caught most of the DEGs $(104,30 \%)$, followed by "transcription" (51,15\%), "signal transduction mechanisms" (50, 14\%), and "replication, recombination and repair" (46, 13\%). Moreover, 40 DEGs and 14 DEGs were annotated respectively to "secondary metabolites biosynthesis, transport and catabolism" and "defense mechanisms", and these genes may uncover the defense mechanisms induced by AMF when plants were suffered from the pathogen infection.

\section{Root DEGs related to defense mechanism}

After blasted with a serial of databases, there were 42 unigenes functionally annotated as the putative "defense mechanism" of all differential treated groups in at least one database (Table 4). Compared with nonmycorrhizal plants, mycorrhizal plants induced 24 unigenes down-regulated and 3 unigenes up-regulated under the condition of no pathogen infection. The biggest drop was c42319.graph_c0 (-6.85) and the biggest rise was c44347.graph_c0 (1.59). Compared with non-mycorrhizal plants, mycorrhizal plants induced 1 unigene (c41443.graph_c0, -3.51) down-regulated and 3 unigenes up-regulated in the presence of the pathogen infection, whilst the biggest rise was c46155.graph_c0 (1.92). Additionally, P. parasitica infection induced 4 unigenes down-regulated and 19 unigenes up-regulated than non- $P$. parasitica infection treatment in mycorrhizal seedlings. In non-mycorrhizal seedlings, $P$. parasitica infection induced 8 unigenes down-regulated 
and 1 unigene up-regulated, indicating that mycorrhizal seedlings performed more actively than nonmycorrhizal seedlings to response to $P$. parasitica infection.
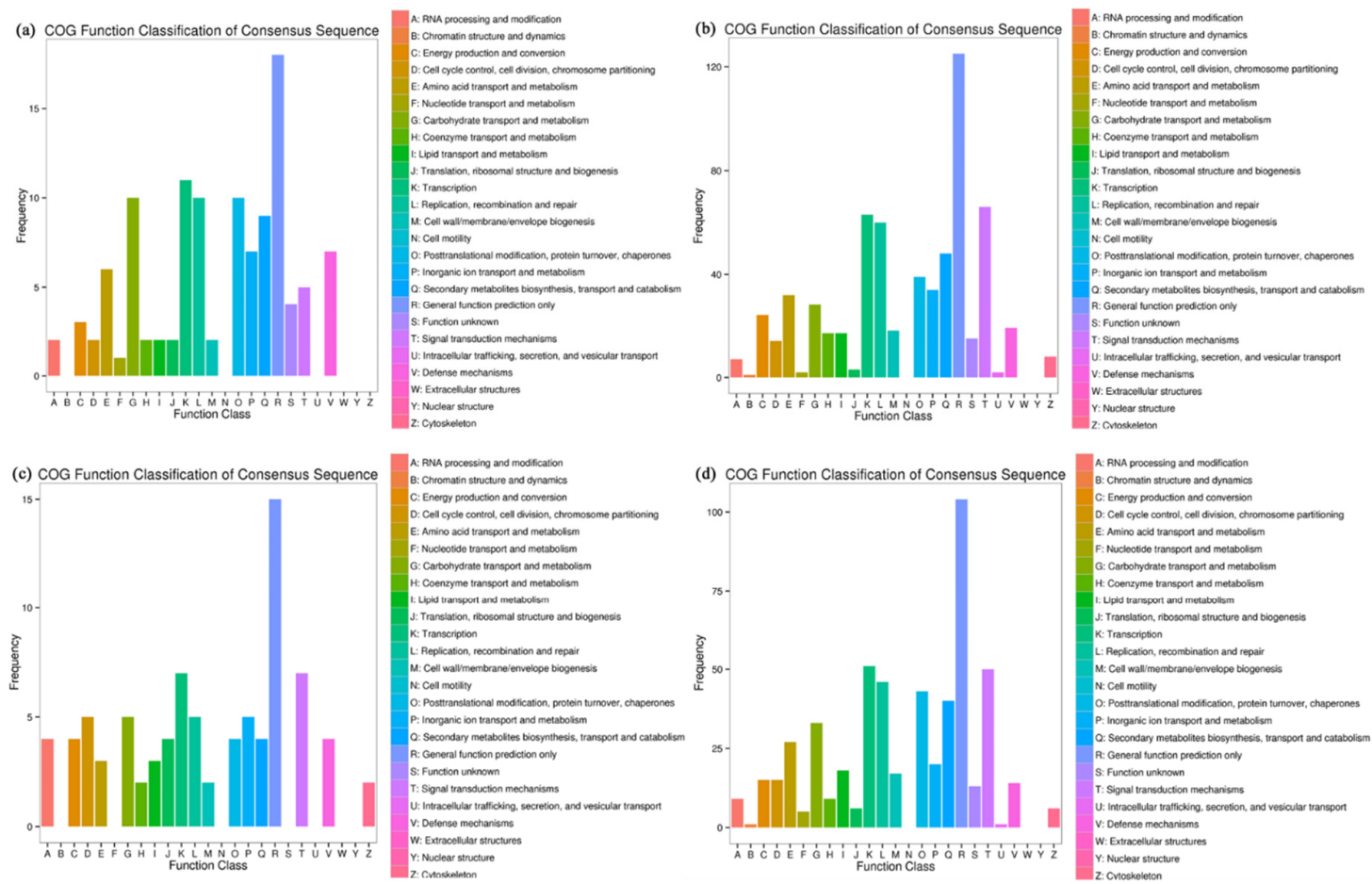

Figure 2. COG functional classification of differentially expressed genes between $-F . m-P . p$ and $-F . m+P$. $p$ (a), $-F \cdot m-P . p$ and $+F \cdot m-P \cdot p$ (b), $-F \cdot m+P . p$ and $+F \cdot m+P \cdot p(\mathrm{c})$, and $+F \cdot m-P \cdot p$ and $+F \cdot m+P \cdot p$ (d), respectively. The abbreviations are the same as in Table 1

\section{Root DEGs related to signal transduction mechanism}

After blasted with a serial of databases, lots of unigenes functionally annotated as the putative "signal transduction mechanism" of all differential treatment groups in at least one database, and the top 10 unigenes with the highest expression in each difference treatment group was selected for analysis. The blast results of the 40 unigenes in the Orange Genome Annotation Project database were shown in Table 5. The 40 unigenes were mostly annotated as calcium-binding protein, protein serine/threonine kinase, phosphoinositol kinase, and leucine-rich repeat receptor protein kinase, which were acted as the mediators of signal transmission and play a role in the middle and downstream of signal transduction in the Orange Genome Annotation Project database. In the $-F . m-P . p$ vs $-F . m+P$. $p$ group, there were 6 unigenes up-regulated and 4 unigenes downregulated in the first 10 expression levels. The most significantly up-regulated gene was c48447.graph_c0 by 1.7 times, and the most significantly down-regulated gene was c43034.graph_c0 by 4.3 times. The annotation information of c47577.graph_c1 and c41969.graph_c1 in the sweet orange database was WRKY19 and MAPK3, respectively, and the expressions of the two genes were collectively down-regulated. In the -F. $m-P . p$ vs $+F . m-P$. $p$ group, the unigenes in the top 10 expressions were up-regulated for 3 unigenes and downregulated for 7 unigenes. The most significant up-regulation was c48165.graph_c0, up by 3.44 times, and its annotation information in the sweet orange database was WRKY46. 
Cheng S et al. (2020). Not Bot Horti Agrobo 48(2):558-571

Table 4. Forty-two DEGs related to defense mechanisms

\begin{tabular}{|c|c|c|c|c|c|c|c|}
\hline No. & Gene ID & $\begin{array}{l}-F \cdot m-P \cdot p \\
\quad \text { vs } \\
-F \cdot m+P \cdot p\end{array}$ & $\begin{array}{l}-F \cdot m-P \cdot p \\
\quad \text { vs } \\
+F \cdot m-P \cdot p\end{array}$ & $\begin{array}{l}-F \cdot m+P \cdot p \\
\quad \text { vs } \\
+F \cdot m+P \cdot p\end{array}$ & $\begin{array}{l}+F \cdot m-P \cdot p \\
\quad \text { vs } \\
+F \cdot m+P \cdot p\end{array}$ & $\begin{array}{l}\text { Gene ID in } \\
\text { Citrus } \\
\text { sinensis }\end{array}$ & Citrus sinensis annotation results \\
\hline 1 & $\begin{array}{l}\text { c17504.graph } \\
\text { _c0 }\end{array}$ & -1.02 & -- & -- & -- & Cs1g13660 & $\begin{array}{c}\text { Pleiotropic drug resistance protein } \\
\text { 1; ABC transporter G family } \\
\text { member } 40\end{array}$ \\
\hline 2 & $\begin{array}{l}\text { c45869.graph } \\
\text { _c0 }\end{array}$ & -4.73 & -5.92 & - & 2.03 & Cs5g13760 & $\begin{array}{c}\text { Pleiotropic drug resistance protein } \\
\text { 3; ABC transporter G family } \\
\text { member } 37\end{array}$ \\
\hline 3 & $\begin{array}{c}\text { c35922.graph } \\
\text { c0 }\end{array}$ & -2.17 & -2.91 & - & -- & Cs5g10270 & $\begin{array}{l}\text { Multidrug and toxin extrusion } \\
\text { protein } 1\end{array}$ \\
\hline 4 & $\begin{array}{l}\text { c43566.graph } \\
\text { _c0 }\end{array}$ & -1.21 & -- & -- & -- & Cs4g17100 & $\begin{array}{c}\text { ABC transporter G family member } \\
\text { 32; Pleiotropic drug resistance } \\
\text { protein } 6\end{array}$ \\
\hline 5 & $\begin{array}{c}\text { c42319.graph } \\
\text { c0 }\end{array}$ & -4.44 & -6.85 & - & -- & Cs2g07290 & $\begin{array}{l}\text { NADPH-dependent methylglyoxal } \\
\text { reductase GRE2 }\end{array}$ \\
\hline 6 & $\begin{array}{c}\text { c44774.graph } \\
\text { c0 }\end{array}$ & 1.88 & -- & -- & 2.04 & Cs3g14510 & Probable carboxylesterase 15 \\
\hline 7 & $\begin{array}{c}\text { c48128.graph } \\
\text { _c3 }\end{array}$ & -1.23 & -- & 1.30 & - & Cslg15710 & $\begin{array}{c}\text { ABC transporter G family member } \\
\text { 36; Pleiotropic drug resistance } \\
\text { protein } 12\end{array}$ \\
\hline 8 & $\begin{array}{c}\text { c46744.graph } \\
\text { c2 }\end{array}$ & -1.15 & -- & 1.21 & -- & Cs7g32530 & $\begin{array}{c}\text { Probable multidrug resistance- } \\
\text { associated protein lethal(2)03659 }\end{array}$ \\
\hline 9 & $\begin{array}{c}\text { c40817.graph } \\
\text { c0 }\end{array}$ & -1.92 & -1.79 & -- & - & Cs7g01770 & MATE efflux family protein FRD3 \\
\hline 10 & $\begin{array}{c}\text { c41832.graph } \\
\text { c0 }\end{array}$ & -- & -1.62 & -- & 1.71 & Cs7g19610 & $\begin{array}{c}\text { E3 ubiquitin-protein ligase } \\
\text { ORTHRUS } 2\end{array}$ \\
\hline 11 & $\begin{array}{c}\text { c30352.graph } \\
\text { _c0 }\end{array}$ & - & -1.74 & -- & 2.04 & Cs3g13090 & $\begin{array}{c}\text { NADPH-dependent aldehyde } \\
\text { reductase ARI1 }\end{array}$ \\
\hline 12 & $\begin{array}{c}\text { c23405.graph } \\
\text { c0 }\end{array}$ & - & -1.03 & -- & -- & Cs6g19470 & $\begin{array}{l}\text { ABC transporter G family member } \\
14\end{array}$ \\
\hline 13 & $\begin{array}{c}\text { c46884.graph } \\
\text { _c0 }\end{array}$ & -- & -1.01 & -- & -- & Cs5g19190 & $\begin{array}{c}\text { Probable carboxylesterase } \\
18 ; \text { Hormone-sensitive lipase }\end{array}$ \\
\hline 14 & $\begin{array}{c}\text { c46035.graph } \\
\text { c0 }\end{array}$ & -- & 1.20 & -- & -- & Cs9g13790 & $\begin{array}{c}\text { Histone-lysine N-methyltransferase, } \\
\text { H3 lysine-9 specific SUVH5 }\end{array}$ \\
\hline 15 & $\begin{array}{c}\text { c40353.graph } \\
\text { c0 }\end{array}$ & - & -2.79 & - & 3.27 & Cs8g09790 & $\begin{array}{l}\text { Bifunctional dihydroflavonol 4- } \\
\text { reductase/flavanone 4-reductase }\end{array}$ \\
\hline 16 & $\begin{array}{c}\text { c23693.graph } \\
\text { c0 }\end{array}$ & -- & -1.00 & -- & -- & Cs9g06490 & Probable carboxylesterase 12 \\
\hline 17 & $\begin{array}{c}\text { c48015.graph } \\
\text { c0 }\end{array}$ & -- & 1.05 & -- & -- & Cs1g26350 & $\begin{array}{c}\text { MATE efflux family protein } 3 \text {, } \\
\text { chloroplastic }\end{array}$ \\
\hline 18 & $\begin{array}{c}\text { c32593.graph } \\
\text { c0 }\end{array}$ & -- & -1.57 & - & 1.75 & -- & ( \\
\hline 19 & $\begin{array}{l}\text { c31739.graph } \\
\text { c0 }\end{array}$ & - & -1.64 & -- & 1.71 & Cs1g18930 & $\begin{array}{c}\text { Pleiotropic drug resistance protein } \\
\text { 1; ABC transporter G family } \\
\text { member } 40\end{array}$ \\
\hline 20 & $\begin{array}{c}\text { c45483.graph } \\
\text { c0 }\end{array}$ & -- & -1.02 & - & -- & Cs5g19630 & $\begin{array}{l}\text { Multidrug and toxin extrusion } \\
\text { protein } 1\end{array}$ \\
\hline 21 & $\begin{array}{c}\text { c44347.graph } \\
\text { _c0 }\end{array}$ & - & 1.59 & -- & -- & Cs7g12620 & MATE efflux family protein 7 \\
\hline 22 & $\begin{array}{c}\text { c17070.graph } \\
\text { c0 }\end{array}$ & -- & -2.04 & -- & 2.08 & Cs1g13730 & $\begin{array}{c}\text { Pleiotropic drug resistance protein } \\
\text { 1; ABC transporter G family } \\
\text { member } 4\end{array}$ \\
\hline 23 & $\begin{array}{c}\text { c41443.graph } \\
\text { _c0 }\end{array}$ & -- & -6.42 & -3.51 & 3.06 & Cs9g11040 & $\begin{array}{c}\text { Multidrug resistance protein } \\
1 ; \mathrm{ABC} \text { transporter B family } \\
\text { member } 19\end{array}$ \\
\hline 24 & $\begin{array}{c}\text { c39782.graph } \\
\text { c1 }\end{array}$ & -- & -2.39 & -- & -- & Cs2g20580 & $\begin{array}{c}\text { Probable tyrosine-protein } \\
\text { phosphatase At } 1 \mathrm{~g} 05000\end{array}$ \\
\hline 25 & $\begin{array}{c}\text { c39825.graph } \\
\text { c0 }\end{array}$ & - & -1.61 & -- & - & Cs9g06450 & Probable carboxylesterase 2 \\
\hline 26 & $\begin{array}{c}\text { c31917.graph } \\
\text { c0 }\end{array}$ & - & -1.45 & -- & 1.47 & Cs9g01170 & $\begin{array}{l}\text { Multidrug resistance protein } \\
\text { homolog } 49\end{array}$ \\
\hline
\end{tabular}


Cheng S et al. (2020). Not Bot Horti Agrobo 48(2):558-571

\begin{tabular}{|c|c|c|c|c|c|c|c|}
\hline 27 & $\begin{array}{l}\text { c47660.graph } \\
\text { _c0 }\end{array}$ & -- & -2.49 & - & 1.60 & Cs7g10200 & $\begin{array}{l}\text { Multidrug resistance-associated } \\
\text { protein 2, 6(Mrp2, 6), abc- } \\
\text { transoprter }\end{array}$ \\
\hline 28 & $\begin{array}{c}\text { c17070.graph } \\
\text { c1 }\end{array}$ & -- & -2.09 & - & 2.62 & Cs1g13730 & $\begin{array}{c}\text { Pleiotropic drug resistance protein } \\
1 ; \mathrm{ABC} \text { transporter } \mathrm{G} \text { family } \\
\text { member } 4\end{array}$ \\
\hline 29 & $\begin{array}{l}\text { c48327.graph } \\
\text { c1 }\end{array}$ & - & -1.43 & - & - & $\mathrm{Cs} 6 \mathrm{~g} 02250$ & $\begin{array}{c}\text { Pleiotropic drug resistance protein } \\
\text { 3; ABC transporter G family } \\
\text { member } 37\end{array}$ \\
\hline 30 & $\begin{array}{c}\text { c42651.graph } \\
\text { _c0 }\end{array}$ & - & -3.25 & - & 1.47 & Cs4g11230 & $\begin{array}{c}\text { Putative multidrug resistance } \\
\text { protein; ABC transporter B family } \\
\text { member } 15\end{array}$ \\
\hline 31 & $\begin{array}{c}\text { c35526.graph } \\
\text { c0 }\end{array}$ & - & -2.92 & - & - & Cs4g20440 & $\begin{array}{c}\text { Putative pleiotropic drug resistance } \\
\text { protein } 7\end{array}$ \\
\hline 32 & $\begin{array}{c}\text { c41867.graph } \\
\text { c0 }\end{array}$ & - & -1.20 & - & - & Cs4g09600 & $\begin{array}{l}\text { Lipid-binding serum glycoprotein } \\
\text { family protein }\end{array}$ \\
\hline 33 & $\begin{array}{c}\text { c46155.graph } \\
\text { c0 }\end{array}$ & - & -- & 1.92 & 1.79 & $\begin{array}{c}\text { orange } 1.1 \mathrm{t} 0 \\
0127\end{array}$ & Pleiotropic drug resistance protein 1 \\
\hline 34 & $\begin{array}{l}\text { c33501.graph } \\
\text { c0 }\end{array}$ & -- & -- & - & -1.11 & Cs2g21180 & $\begin{array}{c}\text { B-cell receptor-associated protein } \\
\text { 31-like containing protein, } \\
\text { expressed }\end{array}$ \\
\hline 35 & $\begin{array}{c}\text { c40502.graph } \\
\text { c1 }\end{array}$ & - & - & - & -1.74 & $\begin{array}{c}\text { orange } 1.1 \mathrm{t} 0 \\
2755\end{array}$ & $\begin{array}{l}\text { Putative NADPH-dependent } \\
\text { methylglyoxal reductase GRP2 }\end{array}$ \\
\hline 36 & $\begin{array}{l}\text { c38995.graph } \\
\text { c0 }\end{array}$ & - & -- & - & -1.20 & Cs2g28050 & $\begin{array}{c}\text { Dual specificity phosphatase, } \\
\text { catalytic domain containing } \\
\text { protein, expressed }\end{array}$ \\
\hline 37 & $\begin{array}{l}\text { c31723.graph } \\
\text { c0 }\end{array}$ & -- & - & -- & -1.84 & Cs6g13330 & $\begin{array}{c}\text { ABC transporter G family member } \\
\text { 22;Pleiotropic drug resistance } \\
\text { protein } 3\end{array}$ \\
\hline 38 & $\begin{array}{c}\text { c30019.graph } \\
\text { c0 }\end{array}$ & -- & -- & -- & 1.01 & Cs6g15300 & Pleiotropic drug resistance protein 2 \\
\hline 39 & $\begin{array}{c}\text { c24119.graph } \\
\text { c0 }\end{array}$ & - & -- & - & 1.72 & - & - \\
\hline 40 & $\begin{array}{l}\text { c48446.graph } \\
\text { _c0 }\end{array}$ & - & -- & - & 1.92 & Cs6g20280 & $\begin{array}{c}\text { ABC transporter B family member } \\
\text { 15; Putative multidrug resistance } \\
\text { protein }\end{array}$ \\
\hline 41 & $\begin{array}{c}\text { c42131.graph } \\
\text { c0 }\end{array}$ & -- & -- & -- & 2.70 & Cs8g05610 & Probable carboxylesterase 13 \\
\hline 42 & $\begin{array}{c}\text { c42785.graph } \\
\text { c0 }\end{array}$ & - & -- & -- & 2.64 & Cs $\lg 16850$ & $\begin{array}{l}\text { Multidrug resistance protein } \\
\text { homolog } 65\end{array}$ \\
\hline
\end{tabular}

The most significant down-regulation was c49730.graph_c0, down by 7.98 times. In the $-F . m+P . p$ vs $+F . m+P$. $p$ group, the unigenes in the top 10 expressions were up-regulated for 2 unigenes and down-regulated for 8 unigenes. The up-regulated genes were c48593.graph_c1 (1.34) and c44707.graph_c0 (1.29). Among the down-regulated genes, the most significant one was c49730.graph_c0, which was down-regulated by 8.19 times. In the $+F . m-P$. $p$ vs $+F . m+P$. $p$ group, the unigenes in the top 10 expressions were up-regulated for 8 genes and down-regulated for 2 genes. The most significant up-regulation was c35123.graph_c0 increased by 5.02 times. The most significant down-regulation was c28686.graph_c0 decreased by 3.16 times. Interestingly, whether trifoliate orange seedlings were infected by the pathogen or not, mycorrhizal plants induced more down-regulated genes than non-mycorrhizal plants.

\section{Root DEGs related to secondary metabolites biosynthesis}

After blasted, lots of unigenes were functionally annotated to the putative "secondary metabolites biosynthesis" of all different treatment groups in at least one database, whilst the top 10 unigenes with the highest expression in each different treatment group was selected for analysis. The blast results regarding the 38 unigenes in the Orange Genome Annotation Project database were shown in Table 6. 
Table 5. Forty DEGs linked to signal transduction mechanisms

\begin{tabular}{|c|c|c|c|c|}
\hline No. & Gene ID & $\begin{array}{l}\text { Expression } \\
\text { situation }\end{array}$ & $\begin{array}{l}\text { Gene ID in Citrus } \\
\text { sinensis }\end{array}$ & Citrus sinensis annotation results \\
\hline 1 & c43034.graph_c0 & -4.30 & Cs9g10150 & Putative protein phosphatase $2 \mathrm{C}$-like protein 44 \\
\hline 2 & c47577.graph_c1 & -2.54 & Cs5g22460 & Probable WRKY transcription factor 19 \\
\hline 3 & c41969.graph_c1 & -2.07 & orange1.1t03917 & Mitogen-activated protein kinase kinase kinase 3 \\
\hline 4 & c48447.graph_c0 & 1.70 & Cs6g06700 & $\begin{array}{l}\text { Probable LRR receptor-like serine/threonine-protein kinase } \\
\qquad \text { At } 1 \text { g } 56140\end{array}$ \\
\hline 5 & c48566.graph_c1 & -1.61 & orange $1.1 \mathrm{t} 01898$ & $\begin{array}{l}\text { Putative disease resistance protein RGA3; Putative inactive disease } \\
\text { susceptibility protein LOV1 }\end{array}$ \\
\hline 6 & c43651.graph_c0 & 1.48 & Cs6g11630 & $\begin{array}{l}\text { Probable receptor-like protein kinase At5g18500; Proline-rich } \\
\text { receptor-like protein kinase PERK5 }\end{array}$ \\
\hline 7 & c33248.graph_c1 & 1.27 & Cs2g27050 & $\begin{array}{l}\text { Copine (Calcium-dependent phospholipid-binding protein) family } \\
\text { protein }\end{array}$ \\
\hline 8 & c45715.graph_c1 & 1.13 & Cs5g02190 & Pleckstrin homology $(\mathrm{PH})$ domain-containing protein \\
\hline 9 & c44894.graph_c0 & 1.04 & -- & 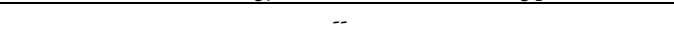 \\
\hline 10 & c48333.graph_c3 & 1.04 & Cs7g25380 & Putative uncharacterized protein Sb02g028510 \\
\hline 11 & c49730.graph_c0 & -7.98 & -- & 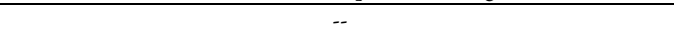 \\
\hline 12 & c28017.graph_c1 & -4.15 & Cs9g12300 & Wall-associated receptor kinase-like 22 \\
\hline 13 & c35123.graph_c0 & -3.58 & orange $1.1 \mathrm{t} 01650$ & Probable inositol polyphosphate 5-phosphatase C9G1.10c \\
\hline 14 & c29587.graph_c0 & -3.57 & Cs8g12690 & Calcium-dependent protein kinase 33 \\
\hline 15 & c41501.graph_c0 & -3.56 & Cs1g16130 & $\begin{array}{l}\text { Probable LRR receptor-like serine/threonine-protein kinase } \\
\qquad \text { At } 1 \text { g05700 }\end{array}$ \\
\hline 16 & c43034.graph_c0 & -3.50 & Cs9g10150 & Putative protein phosphatase $2 \mathrm{C}$-like protein 44 \\
\hline 17 & c48165.graph_c0 & 3.44 & orange 1.1t 00472 & Probable WRKY transcription factor 46 \\
\hline 18 & c28017.graph_c0 & -3.12 & orange $1.1 \mathrm{t} 03406$ & $\begin{array}{l}\text { Probable LRR receptor-like serine/threonine-protein kinase } \\
\qquad \text { At5g48740 }\end{array}$ \\
\hline 19 & c47598.graph_c1 & 2.58 & Cs7g16030 & Disease resistance protein RGA2 \\
\hline 20 & c28686.graph_c0 & 2.42 & Cs5g07160 & Calcium-binding protein CML38 \\
\hline 21 & c49730.graph_c0 & -8.19 & -- & $\begin{array}{l}-- \\
\end{array}$ \\
\hline 22 & c45469.graph_c0 & -1.85 & Cs3g02640 & Leucine-rich repeat receptor-like protein kinase (Fragment) \\
\hline 23 & c29997.graph_c0 & -1.64 & Cs6g21420 & Calcium-binding protein CML42 \\
\hline 24 & c46150.graph_c0 & -1.61 & Cs6g17410 & Diphosphoinositol polyphosphate phosphohydrolase 1 \\
\hline 25 & c46512.graph_c0 & -1.56 & Cs8g20420 & Probable protein phosphatase $2 \mathrm{C} 25$ \\
\hline 26 & c39683.graph_c0 & -1.38 & Cs2g17370 & Diphosphoinositol polyphosphate phosphohydrolase, putative \\
\hline 27 & c48593.graph_c1 & 1.34 & Cs5g21040 & Disease resistance protein RGA2 \\
\hline 28 & c44707.graph_c0 & 1.29 & Cs8g20580 & Probable LRR receptor-like serine/threonine-protein kinase MRH1 \\
\hline 29 & c44894.graph_c0 & -1.27 & -- & $\begin{array}{ll}+- \\
\end{array}$ \\
\hline 30 & c16791.graph_c0 & -1.22 & orange $1.1 \mathrm{t} 04033$ & Protein belonging to uncharacterized protein family UPF0047 \\
\hline 31 & c35123.graph_c0 & 5.02 & orange $1.1 \mathrm{t} 01650$ & Probable inositol polyphosphate 5-phosphatase C9G1.10c \\
\hline 32 & c34446.graph_c1 & 4.74 & Cs3g26960 & Neutral/alkaline nonlysosomal ceramidase family protein \\
\hline 33 & c34446.graph_c0 & 4.45 & Cs3g26960 & Neutral/alkaline nonlysosomal ceramidase family protein \\
\hline 34 & c25753.graph_c0 & 3.33 & Cs1g13850 & Putative uncharacterized protein Sb01g021605 (Fragment) \\
\hline 35 & c28017.graph_c1 & 3.19 & orange $1.1 \mathrm{t} 03406$ & $\begin{array}{l}\text { Probable LRR receptor-like serine/threonine-protein kinase } \\
\qquad \text { At5g } 48740\end{array}$ \\
\hline 36 & c28686.graph_c0 & -3.16 & Cs5g07160 & Calcium-binding protein CML38 \\
\hline 37 & c39912.graph_c0 & 2.98 & Cs3g16870 & Oligopeptide transporter 4 \\
\hline 38 & c41501.graph_c0 & 2.86 & Cs1g16130 & $\begin{array}{l}\text { Probable LRR receptor-like serine/threonine-protein kinase } \\
\text { At } 1 \text { g05700 }\end{array}$ \\
\hline 39 & c47598.graph_c1 & -2.71 & Cs7g16030 & Disease resistance protein RGA2 \\
\hline 40 & c46653.graph_c0 & 2.61 & Cs1g26020 & $\begin{array}{l}\text { Probable LRR receptor-like serine/threonine-protein kinase } \\
\qquad \text { At } 1 \mathrm{~g} 51880\end{array}$ \\
\hline
\end{tabular}

1-10:-F. $m-P . p$ vs $-F . m+P . p ; 11-20:-F . m-P . p$ vs $+F . m-P . p ; 21-30:-F . m+P . p$ vs $+F . m+P . p ; 31-40:+F . m-P . p$ vs

$+F$. $m+P$. $p$. The abbreviations are the same as in Table 1 .

In the $-F . m-P . p$ vs $-F . m+P$. $p$ group, there were one gene (c43852.graph_c0, 1.12) up-regulated and nine genes down-regulated in the unigenes according to the top 10 expression levels. The most significant down-regulation was c29552.graph_c0, down by 5.72 times. In the -F.m-P. $p$ vs $+F . m-P$. $p$ group, the unigenes in the top 10 expression levels all presented down-regulation pattern, and the most significant down-regulation was c29552.graph_c0, down by 7.29 times. In the $-F . m+P . p$ vs $+F . m+P$. $p$ group, only 8 unigenes showed 
differential expression pattern, among which 5 genes were up-regulated and 3 genes were down-regulated. The most significant up-regulation was c41941.graph_c0 increased by 2.1 times. The most significant downregulation was $c 41443$.graph_c0 decreased by 3.51 times. In the $+F . m-P$. $p$ vs $+F . m+P$. $p$ group, the unigenes in the top 10 expression levels all presented up-regulation pattern, whilst the most significant up-regulation was c41443.graph_c0 increased by 4.73 times.

Table 6. 38 DEGs related to secondary metabolites biosynthesis

\begin{tabular}{|c|c|c|c|c|}
\hline No. & DEGs & $\begin{array}{c}\text { Expression } \\
\text { sitiation }\end{array}$ & Citrus sinensis & Citrus sinensis annotation results \\
\hline 1 & c29552.graph_c0 & -5.72 & Cs4g12540 & $\begin{array}{l}\text { Flavonol synthase/flavanone 3-hydroxylase; 1-aminocyclopropane-1- } \\
\text { carboxylate oxidase homolog } 11\end{array}$ \\
\hline 2 & c40823.graph_c0 & -5.40 & Cs3g24170 & Flavonoid 3'-monooxygenase \\
\hline 3 & c45869.graph_c0 & -4.73 & Cs5g13760 & $\begin{array}{l}\text { Pleiotropic drug resistance protein } 3 ; \mathrm{ABC} \text { transporter } \mathrm{G} \text { family member } \\
\qquad 37\end{array}$ \\
\hline 4 & c42319.graph_c0 & -4.44 & Cs2g07290 & NADPH-dependent methylglyoxal reductase GRE2 \\
\hline 5 & c48120.graph_c0 & -1.90 & orange $1.1 \mathrm{t} 00399$ & Ferric reduction oxidase 2 ;NADPH oxidase 1 \\
\hline 6 & c45773.graph_c0 & -1.74 & $\mathrm{Cs} 9 \mathrm{~g} 05770$ & 1,4-beta-D-glucanase; \\
\hline 7 & c48128.graph_c3 & -1.23 & Cs1g15710 & Pleiotropic drug resistance protein 12 \\
\hline 8 & c43566.graph_c0 & -1.21 & Cs4g17100 & $\begin{array}{c}\mathrm{ABC} \text { transporter } \mathrm{G} \text { family member } 32 \text {; Pleiotropic drug resistance protein } \\
6\end{array}$ \\
\hline 9 & c46744.graph_c2 & -1.15 & Cs7g32530 & Multidrug resistance-associated protein 1 \\
\hline 10 & c43852.graph_c0 & 1.12 & Cs2g30870 & Saccharopine dehydrogenase family protein, expressed \\
\hline 11 & c29552.graph_c0 & -7.29 & Cs4g12540 & $\begin{array}{l}\text { Flavonol synthase/flavanone 3-hydroxylase; 1-aminocyclopropane-1- } \\
\text { carboxylate oxidase homolog } 11\end{array}$ \\
\hline 12 & c42319.graph_c0 & -6.85 & Cs2g07290 & NADPH-dependent methylglyoxal reductase GRE2 \\
\hline 13 & c40823.graph_c0 & -6.57 & Cs3g24170 & Flavonoid 3'-monooxygenase \\
\hline 14 & c41443.graph_c0 & -6.42 & Cs9g11040 & Multidrug resistance protein 1 \\
\hline 15 & c45869.graph_c0 & -5.92 & Cs5g13760 & $\begin{array}{l}\text { Pleiotropic drug resistance protein } 3 \text {; ABC transporter G family member } \\
37\end{array}$ \\
\hline 16 & c40233.graph_c0 & -5.03 & Cs6g15620 & $\begin{array}{c}\text { Flavonoid 3'-monooxygenase; Probable (S)-N-methylcoclaurine 3'- } \\
\text { hydroxylase isozyme } 2\end{array}$ \\
\hline 17 & c48217.graph_c0 & -3.93 & Cs4g19530 & Carotenoid $9,10\left(9^{\prime}, 10^{\prime}\right)$-cleavage dioxygenase 1 \\
\hline 18 & c47071.graph_c0 & -3.80 & Cs7g31750 & Flavone synthase; Flavanone 3-dioxygenase \\
\hline 19 & c22631.graph_c0 & -3.47 & orange1.1t01744 & Bacilysin biosynthesis oxidoreductase BacC \\
\hline 20 & c42651.graph_c0 & -3.25 & Cs4g11230 & Multidrug resistance protein 1 \\
\hline 21 & c41443.graph_c0 & -3.51 & Cs9g11040 & Multidrug resistance protein 1 \\
\hline 22 & c40233.graph_c0 & -2.89 & Cs6g15620 & $\begin{array}{c}\text { Flavonoid 3'-monooxygenase; Probable (S)-N-methylcoclaurine 3'- } \\
\text { hydroxylase isozyme } 2\end{array}$ \\
\hline 23 & c47071.graph_c0 & -2.72 & Cs7g31750 & Flavone synthase; Flavanone 3-dioxygenase \\
\hline 24 & c41941.graph_c0 & 2.10 & Cs5g28750 & Flavonol synthase/flavanone 3-hydroxylase \\
\hline 25 & c46155.graph_c0 & 1.92 & orange1.1t00127 & Pleiotropic drug resistance protein 1 \\
\hline 26 & c42229.graph_c1 & 1.91 & Cs7g23790 & Polyamine oxidase \\
\hline 27 & c48128.graph_c3 & 1.30 & Cs1g15710 & Pleiotropic drug resistance protein 12 \\
\hline 28 & c46744.graph_c2 & 1.21 & Cs7g32530 & Multidrug resistance-associated protein 1 \\
\hline 29 & c23556.graph_c1 & 4.73 & Cs3g21210 & $\begin{array}{l}\text { Abscisic acid 8'-hydroxylase 3; 3-epi-6-deoxocathasterone 23- } \\
\text { monooxygenase }\end{array}$ \\
\hline 30 & c46582.graph_c0 & 3.78 & Cs1g23100 & L-ascorbate oxidase homolog \\
\hline 31 & c41962.graph_c0 & 3.56 & Cs2g03380 & $\begin{array}{c}\text { Flavonol synthase/flavanone 3-hydroxylase; Probable 1- } \\
\text { aminocyclopropane-1-carboxylate oxidase }\end{array}$ \\
\hline 32 & c36650.graph_c3 & 3.51 & Cs6g07450 & $\begin{array}{l}\text { Laccase-7; Laccase-9; Laccase-8; Laccase-12; Laccase-24; Laccase-3; } \\
\text { Laccase-14 }\end{array}$ \\
\hline 33 & c41443.graph_c0 & 3.06 & Cs9g11040 & Multidrug resistance protein 1 \\
\hline 34 & c29897.graph_c0 & 3.02 & orange1.1t05246 & Immunoglobulin/major histocompatibility complex \\
\hline 35 & c22631.graph_c0 & 2.86 & orange1.1t01744 & Momilactone A synthase;Glucose 1-dehydrogenase B \\
\hline 36 & c42785.graph_c0 & 2.64 & Cslg16850 & Multidrug resistance protein 1; Multidrug resistance protein homolog 65 \\
\hline 37 & c17070.graph_c1 & 2.62 & Cs 1 g13730 & $\begin{array}{c}\text { Pleiotropic drug resistance protein } 1 \text {; ABC transporter G family member } \\
40\end{array}$ \\
\hline 38 & c49268.graph_c0 & 2.55 & Cs4g20350 & $\begin{array}{c}\text { Gibberellin 3-beta-dioxygenase 1;Flavone synthase; Flavonol } \\
\text { synthase/flavanone 3-hydroxylase }\end{array}$ \\
\hline
\end{tabular}




\section{Discussion}

The construction of gene expression profiles through transcriptome sequencing is an important approach for non-model plants lacking genomic sequence data. Lambais and Mehdy (2010) screened out chitinase- and $\beta$-1,3-glucanase-related DEGs from the transcripts of Phaseolus vulgaris inoculated with Rhizophagus irregularis. Chitinase and $\beta$-1,3-glucanase, as important secondary metabolites in plants, inhibit the infection of pathogenic fungi and improve the disease resistance of plants (Ebrahim et al., 2011). Ward and Weber (2012) used RNA-Seq technology to sequence the resistant strains of raspberry 'Latham' infected by root rot pathogen (Phytophthora rubi), and found that pathogenesis-related protein genes, as well as genes related to tricarboxylic acid cycle and lignin synthesis pathway all presented up-regulation. Cicatelli et al. (2012) and Vangelisti et al. (2018) also demonstrated the positive effects of secondary metabolites induced by AMF in tolerating abiotic stress through RNA-Seq technology. In this work, DEGs related to secondary metabolites biosynthesis presented up-regulation in mycorrhizal plants when suffered the pathogen infection, while DEGs related to secondary metabolites biosynthesis presented down-regulation in non-mycorrhizal plants when suffered the pathogen infection. This indicated that mycorrhizal plants can actively induce the upregulated expression of the genes related to secondary metabolites biosynthesis to respond to the pathogen infection.

Signal transduction is a key link in plant response to external stimulus (Kaur and Gupta, 2005). In this work, compared with $-F . m-P . p$ vs $-F . m+P . p$, the number and expression level of DEGs annotated as receptor-like protein kinases (RLKs) in $+F \cdot m-P . p$ vs $+F \cdot m+P$. $p$ differential gene set were more and higher. This kind of protein kinase is a transmembrane protein kinase located on the plasma membrane surface, which can be activated in large quantities under the action of various stress factors, and participate in the signal transduction process to induce plant disease resistance (Xu et al., 2002). In our work, the expression of gene that annotated as mitogen-activated protein kinase kinase kinase 3 in $-F$. $m-P$. $p$ vs $-F . m+P$. $p$ differential gene set was down-regulated by 2.07 times, which was in accordance with the result of Liu et al. (2017) in mango after infected by Fusarium mangiferae. However, compared with $-F . m-P$. $p$ vs $-F . m+P$. $p$ differential treatment group, DEGs in $+F \cdot m-P$. $p$ vs $+F \cdot m+P$. $p$ were more up-regulated, suggesting that mycorrhizal plants can regulate the up-regulated expression of more genes related to signal transduction to respond to the pathogen infection. However, mycorrhizal inoculation induced the top $10 \mathrm{DEGs}$ related to signal transduction assumed down-regulation of 8 genes and up-regulation of 2 genes when suffered the pathogen infection in comparison with non-mycorrhizal treatment. This might be because mycorrhizal plants selectively mobilize related signal transduction pathways, which needs to be further studied.

Many of the DEGs were linked to cell physiological processes, metabolic processes, stimulus response, catalytic activity, and transcriptional activity in the GO secondary node. Moreover, expression of more genes was induced by AMF inoculation in non-pathogen-infected plants than in pathogen-infected plants. However, from the number of DEGs between $-F$. $m-P . p$ vs $-F . m+P . p$ and $+F . m-P . p$ vs $+F . m+P . p$, it found that mycorrhizal plants induced more gene expression than non-mycorrhizal plants when suffered $P$. parasitica infection. It suggests that although the pathogen infection significantly inhibited the positive effect of AMF inoculation in plants, mycorrhizal plants still regulate various defense mechanisms inside plants to respond to the pathogen infection. In addition, the expression situation of DEGs in secondary metabolites biosynthesis, signal transduction mechanism and defense mechanism in the COG database in the four differentially treatment groups were similar to that in GO secondary node. This further illustrates the important role of AMF inoculation in the response of $P$. parasitica infection. The annotation results of DEGs in each functional classification of each treatment group also provided important information and data for digging the key genes associated with the defense mechanism of trifoliate orange after AMF inoculation. All these unigenes may become the important information resource for future genetic research in mycorrhizal roles in enhancing tolerance of trifoliate orange in response to biotic stress. 


\section{Acknowledgements}

This study was supported by the Scientific and Technological Innovation Team of Outstanding Youth Scientist, Hubei Provincial Department of Education (T201604).

\section{Conflict of Interests}

The authors declare that there are no conflicts of interest related to this article.

\section{References}

Bodker L, Kjoller R, Rosendahl S (1998). Effect of phosphate and the arbuscular mycorrhizal fungus Glomus intraradices on disease severity of root rot of peas (Pisum sativum) caused by Aphanomyces euteiches. Mycorrhiza 8:169-174.

Cicatelli A, Lingua G, Todeschini V, Biondi S, Torrigiani P, Castiglione S (2012). Arbuscular mycorrhizal fungi modulate the leaf transcriptome of a populus alba l. clone grown on a zinc and copper-contaminated soil. Environmental and Experimental Botany 75:25-35.

Dao TT, Linthorst HJ, Verpoort R (2011). Chalcone synthase and its functions in plant resistance. Phytochemistry Reviews 10:397-412.

Ebrahim S, Usha K, Singh B (2011). Pathogeneisi-related (PR)-proteins: Chinase and $\beta$-1,3-glucanase in defense mechanism against malformation in mango (Mangifera indica L.). Scientia Horticulturae 130:847-852.

Esquerré-Tugayé MT, Boudart G, Dumas B (2000). Cell wall degrading enzymes, inhibitory proteins, and oligosaccharides participate in the molecular dialogue between plants and pathogens. Plant Physiology and Biochemistry 38:157-163.

Gao L, Wang Y, Li Z, Zhang H, Ye J, Li G (2016). Gene expression changes during the Gummosis development of peach shoots in response to Lasiodiplodia theobromae infection using RNA-Seq. Frontiers in Physiology 7:170.

Gao WQ, Lu LH, Srivastava AK, Wu QS, Kuča K (2020). Effects of mycorrhizae on physiological responses and relevant gene expression of peach affected by replant disease. Agronomy 10:186.

He JD, Chi GG, Zou YN, Shu B, Wu QS, Srivastava AK, Kuča K (2020). Contribution of glomalin-related soil proteins to soil organic carbon in trifoliate orange. Applied Soil Ecology 154:103592.

He JD, Dong T, Wu HH, Zou YN, Wu QS, Kuča K (2019). Mycorrhizas induce diverse responses of root TIP aquaporin gene expression to drought stress in trifoliate orange. Scientia Horticulturae 243:64-69.

Hu N, Tu XR, Li KT, Ding H, Li H, Zhang HW, Tu GQ, Huang L (2017). Changes in protein content and chitinase and $\beta$-1,3-glucanase activities of rice with blast resistance induced by Ag-antibiotic 702. Plant Diseases and Pests 8:33-36.

Kaur N, Gupta AK (2005). Signal transduction pathways under abiotic stress in plants. Current Science 88:1771-1780.

Kawagoe Y, Shiraishi S, Kondo H, Yamamoto S, Aoki Y, Suzuki S (2015). Cyclic lipopetide iturin a structure-dependently induces defense response in Arabidopsis plants by activating SA and JA signaling pathways. Biochemical and Biophysical Research Communications 460:1015-1020.

Lambais MR, Mehdy MC (2010). Spatial distribution of chitinases and $\beta$-1,3-glucanase transcripts in bean arbuscular mycorrhizal roots under low and high soil phosphate conditions. New Phytologist 140:33-42.

Li Z, Wang YT, Gao L, Wang F, Ye JL, Li GH (2014). Biochemical changes and defense responses during the development of peach gummosis caused by Lasiodiplodia theobromae. European Journal of Plant Pathology 138:195-207.

Liu F, Xiong-Chang OU, Wei JG, Zhan RL, Chang JM (2017). Interaction mechanism between mango and Fusarium mangiferae on transcriptomes. Acta Phytopathologica Sinica 47:224-233.

Ozgonen H, Akgul DS, Erkilic A (2010). The effects of arbuscular mycorrhizal fungi on yield and stem rot caused by Sclerotium rolfsii Sace. in peanut. African Journal of Agricultural Research 5:128-132.

Slezack S, Dumas-Gaudot E, Rosendahl S, Kjoller R, Paynot M, Negrel J, Gianinazzi S (1999). Endoproteolytic activities in pea roots inoculated with the arbuscular mycorrhizal fungus Glomus mosseae and/or Aphanomyces euteiches in relation to bioprotection. New Phytologist 142:517-529. 
Tian L, Wu QS, Kuča K, Rahman MH (2018). Responses of four citrus plants to Phytophthora-induced root rot. Sains Malaysiana 47:1693-1700.

Ueda H, Kugimiya S, Tabata J, Kitamoto H, Mitsuhara I (2019). Accumulation of salicylic acid in tomato plant under biological stress affects oviposition preference of bemisia tabaci. Journal of Plant Interactions 14:73-78.

Vangelisti A, Natali L, Bernardi R, Sbrana C, Turrini A, Hassani-Pak K ... Giordani T (2018). Transcriptome changes induced by arbuscular mycorrhizal fungi in sunflower (Helianthus annuus L.) roots. Scientific Reports 8:4.

Ward JA, Weber CA (2012). Comparative RNA-Seq for the investigation of resistance to Phytophthora root rot in the red raspberry 'Latham'. Acta Horticulturae 946:67-72.

Wu QS, He JD, Srivastava AK, Zou YN, Kuča K (2019). Mycorrhizas enhance drought tolerance of citrus by altering root fatty acid compositions and their saturation levels. Tree Physiology 39:1149-1158.

Xie MM, Zhang YC, Liu LP, Zou YN, Wu QS, Kuča K (2019). Mycorrhiza regulates signal substance levels and pathogen defense gene expression to resist citrus canker. Notulae Botanicae Horti Agrobotanici Cluj-Napoca 47:1161-1167.

Xu ML, Korban SS (2002). A cluster of four receptor-like genes resides in the vf locus that confers resistances to apple scab disease. Genetics 162:1995-2006.

Yap YK, Kodama Y, Waller F, Chung KM, Ueda H, Nakamura K, ... Sano H (2005). Activation of a novel transcription factor through phosphorylation by WIPK, a wound-induced mitogen-activated protein kinase in tobacco plants. Plant Physiology 139: 127-137.

Zhang F, Zou YN, Wu QS, Kuča K (2020). Arbuscular mycorrhizas modulate root polyamine metabolism to enhance drought tolerance of trifoliate orange. Environmental and Experimental Botany 171:103962.

Zhang YC, Zou YN, Liu LP, Wu QS (2019). Common mycorrhizal networks activate salicylic acid defense responses of trifoliate orange (Poncirus trifoliata). Journal of Integrative Plant Biology 61:1099-1111.
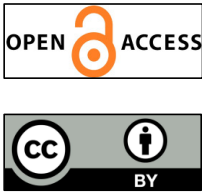

The journal offers free, immediate, and unrestricted access to peer-reviewed research and scholarly work. Users are allowed to read, download, copy, distribute, print, search, or link to the full texts of the articles, or use them for any other lawful purpose, without asking prior permission from the publisher or the author.

License - Articles published in Notulae Botanicae Horti Agrobotanici Cluj-Napoca are Open-Access, distributed under the terms and conditions of the Creative Commons Attribution (CC BY 4.0) License.

(c) Articles by the authors; UASVM, Cluj-Napoca, Romania. The journal allows the author(s) to hold the copyright/to retain publishing rights without restriction. 